\begin{tabular}{|c|c|c|c|}
\hline Article Info & RESEARCH ARTICLE & ARAŞTIRMA MAKALESİ & \\
\hline Title of Article & \multicolumn{2}{|c|}{$\begin{array}{c}\text { Cultural Heritage In The Perspective Of } \\
\text { Destination Marketing. Discovery Of Divriği } \\
\text { Çiğdemli Village }\end{array}$} & \\
\hline $\begin{array}{l}\text { Corresponding } \\
\text { Author }\end{array}$ & \multicolumn{2}{|c|}{$\begin{array}{l}\text { Derya KUTLU } \\
\text { Sivas Cumhuriyet Üniversitesi/ Zara Veysel Dursun Uygulamalı Bilimler Yüksekokulu/ } \\
\text { Sigortacılık ve Risk Yönetimi Bölümü deryautebay@ gmail.com }\end{array}$} & \\
\hline $\begin{array}{l}\text { Received Date } \\
\text { Accepted Date }\end{array}$ & \multicolumn{2}{|c|}{$\begin{array}{l}12.10 .2020 \\
15.02 .2021\end{array}$} & \\
\hline Author / Authors & Derya KUTLU & ORCID: 0000-0003-2258-9250 & \\
\hline How to Cite & \multicolumn{2}{|c|}{$\begin{array}{l}\text { KUTLU, D. (2021). Destinasyon Pazarlaması Perspektifinde Kültürel Miras. Divriği } \\
\text { Çiğdemli Köyünün Keşfi, Kent Akademisi, Volume, } 14 \text { (45), Issue 1, Pages, .59-72. }\end{array}$} & $\begin{array}{l}\text { Kent Akademisi } \\
\text { Urban Academy }\end{array}$ \\
\hline
\end{tabular}

\title{
Destinasyon Pazarlaması Perspektifinde Kültürel Miras. Divriği Çiğdemli Köyünün Keşfi
}

\begin{abstract}
:
Interest in sea, sand and sun-themed holiday concept has been replaced by interest in alternative tourism. People have begun to wonder about the cultural texture of different regions and to make their holiday plans in this direction. The development of destination centers, reaching a sufficient number of demands and ensuring sustainability are developing in parallel with how much they benefit from marketing opportunities. The concept of destination marketing has become important to the extent that can not be ignored. In order for the destination marketing to be successful, it is important to protect these places, to contribute to their development and to ensure that they see the value they deserve in terms of tourism. This, in turn, is only possible through the implementation of effective marketing activities. The aim of the study is to examine how Çiğdemli village, which is a cultural heritage with approximately 1000 years of history in Divriği District of Sivas, should be used in the perspective of Destination Marketing. Exploring the village as an important destination, making it known to people, raising awareness and bringing the tourism potential to the literature are also among the aims of the study. In this context, information was gathered from Divriği municipality and Çiğdemli village association on the activities carried out and planned to take the village under protection as a protected area and contribute to the tourism of the district. In addition, the village was visited and its unique cultural texture was observed. As a result of the research, it was determined that the village is a destination place as a cultural heritage and that the necessary activities are continued to be carried out to become a tourist attraction center.
\end{abstract}

KEYWORDS: Destination Marketing, Cultural Heritage, Divriği, Village of Çiğdemli(Tuğut)

\footnotetext{
${ }^{1}$ Sivas Cumhuriyet University, Zara Veysel Dursun School of Applied Sciences, Department of Insurance and Risk Management, deryautebay@gmail
} 


\section{ÖZ:}

Deniz, kum ve güneş temalı tatil anlayışına olan ilginin yerini alternatif turizme olan ilgi almaya başlamıştır. İnsanlar farklı bölgelerin sahip oldukları kültürel dokuyu merak etmeye ve tatil planlarını bu doğrultuda yapmaya başlamışlardır. Destinasyon merkezlerinin gelişmesi, yeterli sayıda talebe ulaşabilmesi ve sürdürülebilirliğin sağlanabilmesi pazarlamanın imkânlarından ne kadar yararlandığına paralel olarak gelişim göstermektedir. Destinasyon pazarlaması kavramı göz ardı edilemeyecek ölçüde önemli hale gelmiştir. Destinasyon pazarlamasının başarıya ulaşması için söz konusu mekânların koruma altına alınması, gelişimine katkı sağlanması ve turizm anlamında hak ettiği değeri görebilmesinin sağlanması önemlidir. Bu da ancak etkili pazarlama faaliyetlerinin uygulanması ile mümkün olmaktadır. Yapılan çalışmanın amacını, Sivas'ın Divriği ilçesinde bulunan ve yaklaşık 1000 yıllık tarihe sahip kültürel miras olan Çiğdemli Köyünün destinasyon pazarlaması perspektifinde nasıl kullanılması gerektiğinin incelenmesi oluşturmaktadır. Köyün önemli bir destinasyon mekânı olarak keşfedilmesi, insanlara duyurulması, farkındalık yaratılması ve turizm potansiyelinin varlığının literatüre kazandırılması da çalışmanın amaçları arasındadır. Bu bağlamda köyün sit alanı olarak koruma altına alınması, ilçenin turizmine katkı sağlaması için yapılan ve yapılması planlanan faaliyetler konusunda Divriği belediyesi ve Çiğdemli Köyü derneğinden bilgiler toplanmıştır. Ayrıca köye ziyaret gerçekleştirilerek, eşsiz kültürel doku gözlemlenmiştir. Araştırma sonucunda köyün bir kültürel miras olarak destinasyon mekânı olduğu, turistik çekim merkezi haline gelmesi için gerekli faaliyetlerin yapılmasına devam edildiği belirlenmiştir.

ANAHTAR KELIMELER: Destinasyon Pazarlaması, Kültürel Miras, Divriği, Çiğdemli Köyü

\section{"Destinasyon Pazarlaması Perspektifinde Kültürel Miras. Divriği Çiğdemli Köyünün Keşfi”}

\section{GíRiș:}

Bir şehre ait tarihi ve kültürel miras, doğal güzellikler gibi değerler kimlik oluşturulması ve destinasyonların pazarlaması açısından oldukça önem taşımaktadır. Günümüzde hızla artan bir ivmeyle gelişen turizm sektörü içerisinde bulunan bu değerlerin sahip olduğu çekicilikler destinasyonlara büyük katkılar sağlamaktadır. Dünyada çeşitli çekiciliklere sahip birçok destinasyon mekânı bulunmaktadır. Bu destinasyon mekânlarının benzerleri içerisinde farklılaşmasını sağlamak için etkin destinasyon pazarlaması planlarının yapılması gerektirmektedir. Böylelikle turistlere o mekâna özgü deneyimler yaşatılabilmektedir. Çünkü destinasyon mekânlarında turistlere sunulan farklı hizmetler ile turizm pazarı için pay almak amaçlanmaktadır. Ayrıca destinasyon pazarlamasının etkin yapılması ile bölge için ekonomik katkı da sağlanmış olmaktadır.

Bir yerin destinasyon mekânı olarak adlandırılabilmesi için doğal ve kültürel zenginliklere sahip olması, bölgeyi ziyaret edecek insanlar için bölgeye özgü aktiviteler oluşturulması, konaklama yerlerinin varlığı ve yeterliliği, bölgeye ulaşımın kolaylıkla sağlanabilir olması, kamusal olanakların olması, belirli bir marka imajına sahip olması gibi özellikler gerekmekte ve sınırları belli bir coğrafi alan olarak destinasyon alanının belirtilmesi önem taşımaktadır (Bahar ve Kozak, 2005:78). Destinasyon mekânlarının coğrafi sınırları Kültür ve Turizm Bakanlığı tarafından oluşturulmaktadır.

Günümüzde destinasyon mekânlarına talep oluşturulması pazarlama faaliyetlerinin gerçekleştirilmesi ile mümkün olmaktadır. Destinasyona ait marka kimliği oluşturmak, onu benzerlerinden ayıran özellikleri ortaya çıarmak, yapılan pazarlama faaliyetlerini gerçekleştirirken ortaya çıkarılan bu özelliklere vurgu yapmak söz konusu destinasyonun rekabetçi turizm pazarında yer edinmesini sağlayacak önemli öğelerdir. Ayrıca destinasyon mekânını yöneten kişiler kadar burada yaşayan insanlar da destinasyon pazarlaması konusunda büyük sorumluluk taşımaktadır. Çünkü burada yaşamını sürdüren insanlar söz konusu destinasyonun en çok öneme sahip pazarlama elemanlarıdır. Dolayısıyla destinasyon pazarlamasının başarıya ulaşması ve uzun vadede bu başarıyı elde tutabilmesi için halkın da destinasyona yerleştirilmesi ve bilinçlendirilmesi için gerekli ve yeterli çalışmaların yapılması gerekmektedir.

Kültürel miras değerlerinin farkındalı̆̆ının oluşturulması ve turistik çekim merkezi olarak değer görmesinin sağlanması konusunda destinasyon pazarlaması büyük öneme sahiptir. Sivas'ın Divriği ilçesinde bulunan ve yaklaşık Kategorik ayrımların öneminin arttığı zorunlu durumlar haricinde başlık düzey sayısı üç ile sınırlı tutulmalıdır.

1000 yıllık tarihe sahip kültürel miras olan ve sit alanı olarak koruma altına alınan Çiğdemli Köyü destinasyon pazarlaması perspektifinden incelenmiştir. Çiğdemli Köyünün turizm potansiyeli hakkında bilgiler elde edilmiştir. 
Destinasyon pazarlaması kapsamında köy ile ilgili yapılması gerekenlerin neler olması gerektiği konusunda önerilerde bulunulmuştur. Destinasyon pazarlamasının doğru doğru stratejiler geliştirilerek uygulandığında köyün ilçe turizmine ciddi katkılar sağlayacağı açıktır. Ayrıca köye ait çekilmiş resimler de Divriği Belediyesi'nden temin edilmiş ve çalışmaya eklenmiştir.

\section{Destinasyon Pazarlaması}

Destinasyon kelimesini Türk Dil Kurumu "varılacak yer" olarak tanımlamıştır. "Yer" terimi şehirler, şehir bölgeleri, bölgeler, topluluklar, alanlar, eyaletler ve uluslar gibi her türlü yeri ifade etmek için kullanılır. Yer bir ulus devlettir, jeopolitik bir fiziksel mekândır; bir bölge veya eyalet; kültürel, tarihi veya etik açıdan sınırlanmış bir bölge; merkezi bir şehir ve çevresindeki nüfus; çeşitli tanımlanabilir özelliklere sahip bir piyasa; bir endüstrinin ana üssü ve benzer endüstriler ve tedarikçilerin kümelendiğí; insanlar arasındaki ilişkilerin psikolojik bir niteliğidir (Kotler, Hamlin, Rein ve Haider, 2002:4). İnsanlar destinasyonlara bir uğrak yeri ya da mola noktası olarak değil tatil, gezip görme gibi belirli bir amaç için gelmektedirler. Yani destinasyon mekânlarını seçmektedirler. Söz konusu destinasyon mekânları bir köy, kasaba, ilçe olabileceği gibi şehir, bölge, eyalet, ülke gibi daha büyük ölçekli yerleşim yerleri de olabilmektedir.

Destinasyon mekânları da tıpkı işletmeler gibi insanları çekebilmek için pazarlama stratejilerinden yararlanılarak yönetilmelidir. Destinasyonlar, ziyaretçilerin ve yatırımcıların beklentileri karşılandı̆̆ında başarılı olmaktadır. Bu başarının temelini destinasyonların etkin bir şekilde pazarlanabilmesi oluşturmaktadır. Destinasyon pazarlaması; hedef pazarların ihtiyaçlarını karşılayacak bir yer tasarlamak anlamına gelmektedir. (Kotler vd., 2002:183). Günümüzde destinasyon mekânlarının turistleri, fabrikaları, şirketleri ve yetenekli insanları çekmesi ve aynı zamanda bu yerlerin yönetimi için stratejik pazarlama yönetimi araçları ve bilinçli markalaşmanın benimsenmesi gerekmektedir. Dolayısıyla destinasyon pazarlaması; yer için olumlu bir imaj oluşturmak ve işletmeleri, turistleri, kurumları, etkinlikleri o yeri çekici kılmak şeklinde amaçlar için kullanılmaktadır (Kotler ve Gertner, 2002:253).

Destinasyon pazarlaması süreçlerden oluşmaktadır. Bu süreçler; pazarlama firsatlarının analiz edilmesi, pazarlama stratejilerinin geliştirilmesi, pazarlama programlarının planlanması ve pazarlama çabasının yönetilmesinden oluşmaktadır (Kotler, 1997:90). Şekil 1'de, "bir destinasyon pazarlama sürecindeki unsurlar" üç perspektifte ele alınmıştır. Bunlar; üreticiler, pazar ve tüketicilerdir. Süreç öğeleri ise; kaynaklar, ürün, pazarlama stratejileri ve ölçümleri, müşteri popülasyonları, bölümleme ve stratejilerden oluşmaktadır (Ashworth ve Voogd, 1994:43). 


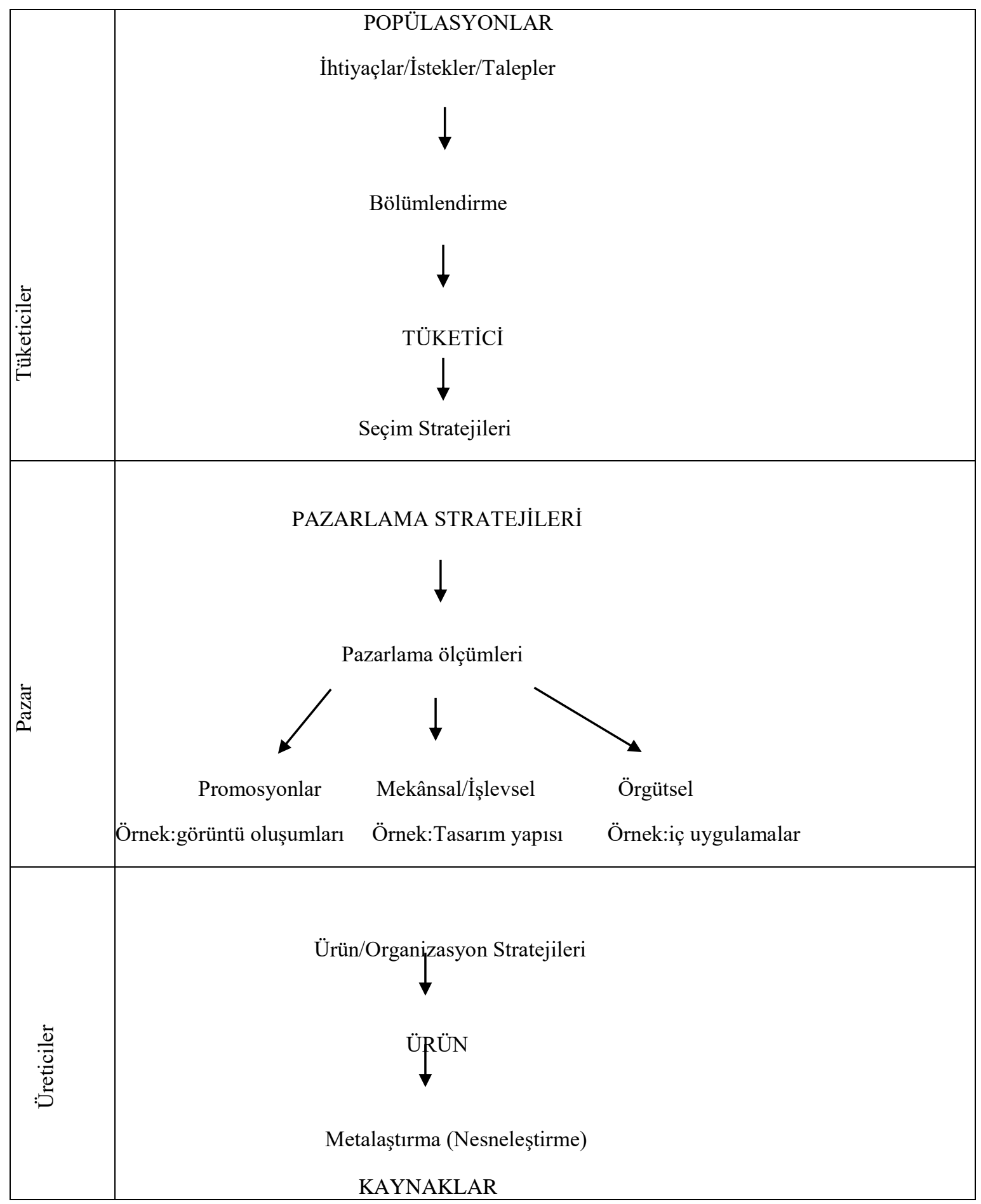

Şekil 1. Bir Destinasyon Pazarlama Sürecindeki Unsurlar (Kaynak: Ashworth ve Voogd, 1994:43)

Öğelerin her biri geleneksel pazarlamadakilerden farklıdır. Bu farklılıklar, basit bir yöntem aktarmasından daha fazlası olan destinasyon pazarlamasının ayırt edici karakterini belirlemektedir (Ashworth ve Voogd, 1994:43). Destinasyon pazarlaması, seçilen bir tesis paketinin satışını veya tüm yerin onunla ilişkili resimler aracılığıyla satışını içerebilmektedir. Destinasyonlar, farklı amaçlara yönelik birçok farklı tüketici grubuna ürün olarak pazarlanmaktadır. Kamu, yarı kamu ve özel kuruluşlar bir destinasyon ürünün üreticileri olabilmektedirler. Müşteriler destinasyonlar 
arasından seçim yapmakta özgürdürler. Destinasyonların fiyatlandırılması genellikle dolaylıdır, soyuttur ve genellikle parasal olmamaktadır. Reklam ve tanıtım, birçok olası pazarlama önlemlerinden yalnızca biridir. Ölçülerin seçimi, kuruluşun pazarlama stratejileri ve hedeflerinin seçimine bağlı olmaktadır. Her strateji, farklı pazarlama faaliyetleri karışımı gerektirebilmekte ve çok sayıda strateji aynı anda oluşturulabilmektedir (Porter, 2001:155-156; Kotler ve Gertner, 2002:253).

Destinasyon pazarlamasının seviyeleri; hedef pazarları, pazarlama faktörlerini ve planlama grubunu içermektedir. Bu seviyeler arasındaki ilişki Şekil 2'de, özetlenmiştir (Kotler vd., 2002:46):

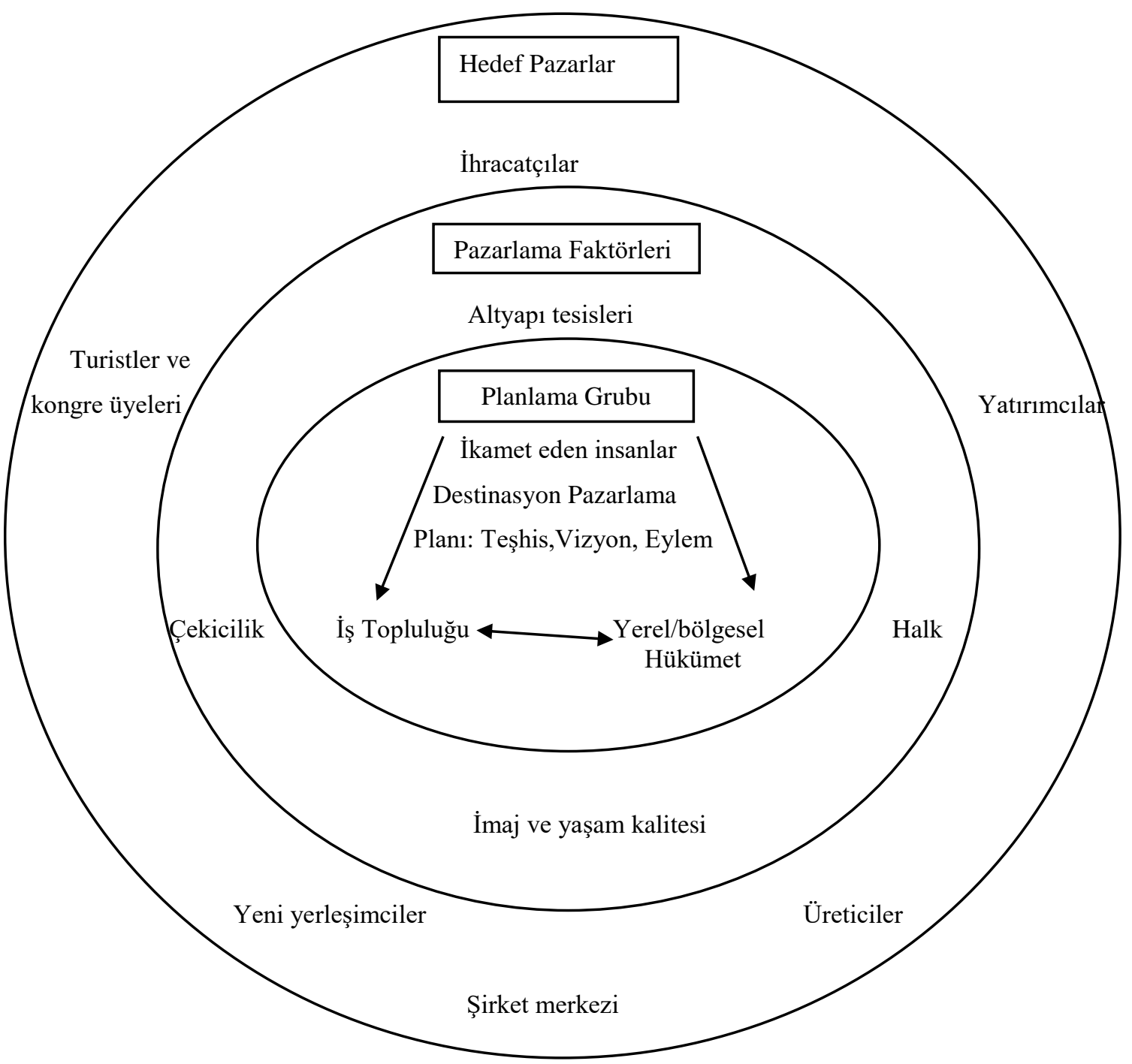

Şekil 2. Destinasyon Pazarlamasının Seviyeleri( Kaynak: (Kotler vd., 2002:46)

Hedef pazarlar, bir yerin pazarlama mesajları göndermeyi seçtiği seçilmiş segmentler ve müşteriler anlamına gelmektedir. Hedef pazarlar; ihracatçılar, turistler ve kongre üyeleri, yeni yerleşimciler, üreticiler, şirket merkezi ve yatırımcılardan oluşmaktadır. Pazarlama faktörleri, yerin çekiciliği ve altyapısı, insanları, imajı ve yaşam kalitesidir. Planlama grubu ise destinasyon pazarlamasının planlama ve kontrol sürecinden sorumludur. Bir destinasyonun pazarlaması yapılırken hedef kitlenin zihninde o yer hakkında olumlu bir konumlandırma yapılmalıdır. Yani insanların söz konusu yeri ziyaret etmelerinin gerekliliği konusunda bir algı oluşturulmalıdır. Bu algı oluşturulurken 
destinasyonu çekici kılan tüm unsurlar kullanılmalıdır. Destinasyonun sahip olduğu imaj da, insanların ziyaret etme nedeni olabilmektedir. İyi bir imaja sahip olan destinasyon, tıpk1 ürünlerde olduğu gibi tavsiye edilmekte ve ziyaret edilen bir mekân haline gelmektedir. Tüm bunların yanında sıkça ziyaret edilen ve tercih edilen bir destinasyonun marka haline gelmesi de kaçınılmaz olmaktadır.

Bir destinasyonun yaşanabilirliğini, yatırım yapılabilirliğini ve ziyaret edilebilirliğini iyileştirmek için çeşitli düzenlemeler yapılabilir. Bunlar (Kotler, Asplund, Rein ve Haider, 1999:125);

1) Karakter olarak yerleştirin: Estetik kentsel tasarım, gelişimi etkileyen konularda değerlerin ve karar almanın nasıl bir araya geldiğini yansıttığı için, "yerin hissini” büyük ölçüde ortaya çıkarmakta ve bir yer hakkında bir açıklama yapmaktadır.

2) Sabit bir ortam olarak yerleştirin: Doğal çevre ile uyumlu bir temel altyapı, kentsel tasarımı mümkün kılmaktadır, ancak bir yerin büyümesini garanti edemez, ancak yokluğu ciddi bir sorumluluktur. Stratejik pazar planlaması, çeşitli altyapılı teklifleri akıllıca ve yaratıcı bir şekilde ele almalıdır. Ayrıca, altyapı geliştirmenin genel yer geliştirme önceliklerine göre ayarlanması gerekir.

3) Servis sağlayıcı olarak yerleştirin: Destinasyon tasarımı ve altyapı gibi, başarılı yerler de bir destinasyonun birincil cazibesi ve ürünü olarak pazarlanabilen iyi kamu hizmetleri gerektirmektedir. Güvenliği, eğitimi ve cazibe merkezlerini iyileştirmeye yönelik programlar geliştirilmelidir.

4) Eğlence ve rekreasyon olarak yerleştirin: $\mathrm{Bu}$ işlevi yerine getiren geleneksel kurumlar restoranlar, parklar, hayvanat bahçeleri, spor sahaları ve daha kapsamlı cazibe merkezleri kombinasyonları ortaya çıkmaktadır.

\section{Kültürel Miras ve Çiğdemli Köyü}

Kültür kavramı Türk Dil Kurumu tarafından 6 farklı şekilde tanımlanmıştır. Buna göre kültür; "tarihsel, toplumsal gelişme süreci içinde yaratılan bütün maddi ve manevi değerler ile bunları yaratmada, sonraki nesillere iletmede kullanılan, insanın doğal ve toplumsal çevresine egemenliğinin ölçüsünü gösteren araçların bütünü, hars, ekin'dir". Bir başka tanıma göre ise kültür; "Bir topluma veya halk topluluğuna özgü düşünce ve sanat eserlerinin bütünüdür" (URL 9). Kültür ve Turizm Bakanlığı'nın yaptığı tanıma göre; "Kültür, bir toplumu diğer toplumlardan farklı kılan, geçmişten beri değişerek devam eden, kendine özgü, sanatı, inançları, örf ve adetleri, anlayış ve davranışları ile onun kimliğini oluşturan yaşayış ve düşünüş tarzıdır. Topluma bir kimlik kazandıran, dayanışma ve birlik duygusu verdiği toplumda düzeni de sağlayan maddi ve manevi değerlerin bütünüdür” (URL 3).

1964 tarihinde imzalanan Venedik Tüzüğü içerisinde yer alan "tarihi anıt" kavramının tanımı kültürel miras kavramının tanımlanması için yol gösterici olmuştur. Nitekim tüzüğün ilk maddesinde konu edilen "Tarihi anıt kavramı sadece bir mimari eseri içine almaz, bunun yanında belli bir uygarlığın, önemli bir gelişmenin, tarihi bir olayın tanıklığını yapan kentsel ya da kırsal bir yerleşmeyi de kapsamaktadır. Bu kavram yalnızca büyük sanat eserlerini değil, ayrıca zamanla kültürel anlam kazanmış daha basit eserleri de kapsar" (URL 11) tanımı ile kültürel mirasın yalnızca somut varlıklardan oluşmadığı, bununla birlikte soyut kültürel varlıkları da içinde barındıran bir yaklaşımla bakılması gerçekliğini ortaya çıkarmıştır. Kültürel miras; "Birleşmiş Milletler Eğitim, Bilim ve Kültür Örgütü Genel Konferans1 17 Ekim-21 Kasım 1972 tarihleri arasında Paris'te toplanan on yedinci oturumunda, "Dünya Kültürel ve Doğal Mirasının Korunmasına Dair Sözleşme" (URL 8) ile tanımlanmıştır. "Bu sözleşmenin amaçları bakımından aşağıdakiler "kültürel miras" sayılmasına karar verilmiştir (URL 8) :

"Anıtlar: Tarih, sanat veya bilim açısından istisnaî evrensel değerdeki mimari eserler, heykel ve resim alanındaki şaheserler, arkeolojik nitelikte eleman veya yapılar, kitabeler, mağaralar ve eleman birleşimleri.

Yapı toplulukları: Mimarileri, uyumlulukları veya arazi üzerindeki yerleri nedeniyle tarih, sanat veya bilim açısından istisnaî evrensel değere sahip ayrı veya birleşik yapı toplulukları.

Sitler: Tarihsel, estetik, etnolojik veya antropolojik bakımlardan istisnaî evrensel değeri olan insan ürünü eserler veya doğa ve insanın ortak eserleri ve arkeolojik sitleri kapsayan alanlar" 
Ayrıca imzalanan sözleşme ile anlaşmanın tarafları olan devletlerin sahip oldukları kültürel ve doğal mirasların yeniden tanımını yapma, koruma, restorasyon çalışmalarını yapma ve gelecek kuşaklara en iyi şekilde devretmeleri konusunda yükümlülükler getirilmiştir. Bununla birlikte kültürel miras sadece fiziki özelliklere sahip olan miras değil; gelenek- görenek, inançlar, sanat, bir yere ait fiziki atmosfer, mistik hava gibi somut olmayan unsurları da içine almaktadır (Aksoy vd., 2012:5). 2003 yılında UNESCO 32. toplantısı gerçekleştirilmiş ve bu toplantıda "Somut Olmayan Kültürel Miras'ın Korunması Sözleşmesi” imzalanarak kültürel mirasın somut ve somut olmayan şeklinde iki yönlü ele alınmasına karar verilmiştir. Somut olmayan kültürel miras tanımlaması şu şekilde yapılmıştır: "Somut olmayan kültürel miras" toplulukların, grupların ve kimi durumlarda bireylerin, kültürel miraslarının bir parçası olarak tanımladıkları uygulamalar, temsiller, anlatımlar, bilgiler, beceriler ve bunlara ilişkin araçlar, gereçler ve kültürel mekanlar- anlamına gelir. Kuşaktan kuşağa aktarılan bu somut olmayan kültürel miras, toplulukların ve grupların çevreleriyle, doğayla ve tarihleriyle etkileşimlerine bağlı olarak, sürekli biçimde yeniden yaratılır ve bu onlara kimlik ve devamlılık duygusu verir; böylece kültürel çeşitliliğe ve insan yaratıcılığına duyulan saygıya katkıda bulunur. İşbu Sözleşme bağlamında, sadece, uluslararası insan hakları belgeleri esaslarına uyan ve toplulukların, grupların ve bireylerin karşılıklı saygı gereklerine ve sürdürülebilir kalkınma ilkelerine uygun olan somut olmayan kültürel miras göz önünde tutulacaktır” (URL 8).

Ülkemizin sahip olduğu somut kültürel miraslar; kazı araştırmaları, müzecilik faaliyetlerini kapsamaktadır. Aralık 2019 itibariyle UNESCO’ya kaydedilen somut olmayan kültürel mirasları ise şöyledir (URL 12) :

1. Meddahlık Geleneği (2008)

2. Mevlevi Sema Törenleri (2008)

3. Âşıklık Geleneği (2009)

4. Karagöz (2009)

5. Nevruz (Azerbaycan, Hindistan, İran, Kırgızistan, Özbekistan ve Pakistan ile ortak dosya (2009) (2016 yılında dosya Afganistan, Azerbaycan, Hindistan, Irak, İran, Kazakistan, Kirgızistan, Özbekistan, Pakistan, Tacikistan ve Türkmenistan katılımı ile genişletilmiştir)

6. Geleneksel Sohbet Toplantıları (Yaren, Barana, Sıra Geceleri ve diğer, 2010)

7. Alevi-Bektaşi Ritüeli Semah (2010)

8. Kırkpınar Yağlı Güreş Festivali (2010)

9. Geleneksel Tören Keşkeği (2011)

10. Mesir Macunu Festivali (2012)

11. Türk Kahvesi ve Geleneği (2013)

12. Ebru: Türk Kâğıt Süsleme Sanatı (2014)

13. İnce Ekmek Yapımı ve Paylaşımı Geleneği: Lavaş, Katrıma, Jupka, Yufka (Azerbaycan, İran, Kazakistan,

Kırgizistan ve Türkiye ile ortak dosya) (2016)

14. Geleneksel Çini Sanatı (2016)

15. Bahar Bayramı Hidırellez (Makedonya ile ortak dosya) (2017)

16. Dede Korkut-Korkut Ata Mirası: Kültürü, Efsaneleri ve Müziği (Azerbaycan ve Kazakistan ile Ortak Dosya, 2018)

17. Geleneksel Türk Okçuluğu (2019)

\section{Acil Koruma Gerektiren Somut Olmayan Kültürel Miras Listesi}

\section{Islik Dili (2017)}

Ülkemizde kültürel miras olarak koruma altına alınan sit alanlarından birisi de Sivas’ın Divriği ilçesinde bulunan ve yaklaşık 1000 yıllık tarihi geçmişe sahip Çiğdemli Köyüdür. Köy; Türklerin Orta Asya'dan Anadolu'ya göç ettikleri sırada uğradıkları yerlerden biri olmakla birlikte, benzersiz mimarisi ile keşfedilmeyi beklemektedir. "Divriği'nin günümüze kadar ismi değişmeden gelen nadir köylerimizden biridir. Son otuz, kırk yıl içinde önceleri Ağılcık, daha sonra da Çiğdemli ismini almasına rağmen halk tarafından Tuğut (Toğut) olarak bilinmektedir. Evliya Çelebi Seyahatnamesi'nin üçüncü cildinin 274. sayfasında (Dersaadette İkdam Matbaası Rumi 1314 Çeviri Ahmet Cevdet) Evliya Çelebi'nin Sivas Diyarbakır seyahatinde Tuğut'taki handa da konakladıklarını yazmış ve buranın 150 haneli bağlı bahçeli mamur bir köy olduğu vurgulanmıştır. Özellikle de isminin Tuğut olması dikkati çekmektedir. Divriği'nin en geniş arazisine sahip olmaları buradaki halkı çok yönlü imalata götürmüştür. Bugün dahi yoğurt, peynir ve kaymak ambarıdır. Hristiyan olan bu belde dokuzuncu yüzyılda İslamiyet'le tanışmış, Mengücekler döneminde gelişmiş ve Yunus Emre’nin Timisi köyünde üç yıl kalması diğer köyler gibi buradaki halkında irşat olmasına sebep 
olmuştur. Tuğut köyünün mamur olması zamanla eğe tarafından gelen göçlerle (Dulkadir oğullarından bir boy) daha da gelişmiştir. 19. yüzyılda eğitimini tamamlayarak İstanbul'dan geri gelen şahıslar ise köylerine eşine rastlanmayan binalar, hanlar ve mahsenler yapıp köylerini zirveye çıkartmışlardır” (URL 1).

\section{Araştırmanın Amacı}

Destinasyonların sahip olduğu değerler onlara farkındalık kazandırmaktadır. Dolayısıyla doğal ve kültürel çekiciliklere sahip destinasyonlar için bilinilirlik sağlamak, buralara turistleri çekmek ve bunun sürdürülebilirliğini sağlamak için doğru oluşturulacak destinasyon pazarlaması stratejilerine ihtiyaç vardır. $\mathrm{Bu}$ stratejiler; konumlandırmanın yapılması, destinasyon imajının oluşturulması ve markalaştırmanın sağlanması şeklinde oluşturulabilmektedir. Bu stratejilerin oluşturulması için ise mevcut değerlerin farkında olmak ve bu değerlerin korunmasını sağlamak büyük önem arz etmektedir. Bu açıdan bakıldığında turizm, doğal ve kültürel mirasın korunması için önemli bir dayanaktır.

Her yıl milyonlarca turisti ağırlayan Türkiye, Dünya Turizm Örgütü'nün 2019 yılında belirlenen rakamlarına göre en fazla ziyaret edilen ülkeler sıralamasında 6. ülke olmuştur. Ülkemizde deniz, kum, güneş üçlüsünün yer aldığı doğal güzelliklere sahip pek çok destinasyon bulunmaktadır. Bunun yanında tarihi ve kültürel anlamda da ülkemiz çok sayıda medeniyete ev sahipliği yapmış olup kültürel ve tarihi miras açısından da oldukça zengin değerlere sahiptir. Bunlardan birisi de kültürel miras olarak çekiciliğe sahip bir destinasyon olan Divriği'nin Çiğdemli Köyüdür. Bu köy turizm anlamında insanların zihinlerinde henüz yer edinememiştir. Çiğdemli Köyü sahip olduğu eşsiz mimarı ve asırlık geçmişi ile turizme mutlaka kazandırılması gereken ender kültürel miraslardan birisidir. Bu sebeple bu araştırma ile sit alanı olarak koruma altına alınan Sivas'ın Divriği ilçesinde bulunan ve yaklaşık 1000 yıllık tarihe sahip kültürel miras olan Çiğdemli Köyünün destinasyon pazarlaması perspektifi ile incelenmesi amaçlanmıştır. Köyün önemli bir destinasyon mekânı olduğunun keşfedilmesi, insanlara duyurulması, farkındalık yaratılması ve turizm potansiyelinin varlığının literatüre kazandırılması da çalışmanın amaçları arasındadır.

\section{Verilerin Toplanması Ve Değerlendirilmesi}

Çalışma için nitel araştırma içerisinde bulunan doküman incelemesi ve gözlem teknikleri kullanılmıştır. Bu bağlamda; Divriği Belediyesi ve Çiğdemli Köyü derneğinden elde edilen bilgi ve dokümanların incelemesinin yanı sıra köy ziyaret edilmiş ve kültürel dokusu yerinde gözlemlenmiştir. Ayrıca Çiğdemli Köyü ile ilgili basında çıkan haberler taranmış, çalışmaya dahil edilmiştir. Köyün tarihi ve sahip olduğu değerleri, sit alanı olarak koruma altına alınma süreci, turizme kazandırılması için destinasyon pazarlaması çerçevesinde neler yapıldığı ve yapılabileceği, köyün dernek çalışmalarının neler olduğu konularında bilgiler toplanmışır. Toplanan bu bilgiler ışığında Çiğdemli Köyünün mevcut potansiyeli göz önüne alınarak daha etkin bir şekilde nasıl pazarlanabileceği, köyün tanınır olmasına katkı sağlamak ve turistlerin dikkatlerinin çekilmesi için gerekli destinasyon pazarlama faaliyetlerinin neler olabileceği konusunda önerilerde bulunulmuştur. Araştırma zaman kısıtı nedeniyle doküman incelemesi ve gözlem sonucu elde edilmeye çalışılan bilgiler ışığında yapılmıştır. Daha sonraki çalışmalar için gerek ilçe yönetimindeki kişiler, gerekse ilçe ve köy halkı ile yüz yüze görüşmeler yapılmak suretiyle Çiğdemli Köyü ile ilgili geniş bir veri setine ulaşma imkânı elde edilebilecektir.

Çiğdemli Köyünün koruma altına alınması için başvuru yapılmış ve gerekli değerlendirmeler yapıldıktan sonra, 22.06.2020 tarihinde, 6080 sayılı kararı ile Kültür ve Turizm Bakanlığı Kültür Varlıkları ve Müzeler Genel Müdürlüğü tarafından kültürel miras olarak sit alanı şeklinde koruma altına alınmıştır. Bu koruma kararı; Sivas İl Kültür ve Turizm Müdürlüğünün sosyal medya hesapları üzerinden duyurulmuştur. Bu duyurum şu şekildedir: Köyün yöresel köy mimarisi özellikleri taşıyarak görülmeye değer farklı mimariye sahip olduğu ve köyde yer alan muhtelif yapıların (konut, köprü, cami, çeşme, mahzen gibi) mimari, mahalli, tarihsel, estetik ve sanat özellikleri açısından sahip olduğu değerler bakımından 2863 sayılı kanun kapsamında "Korunması Gerekli Taşınmaz Kültür Varlığı" olarak tescil edilip kentsel sit alanı ilan edilmiştir. Köyün sit alanı olarak koruma altına alındığı hakkındaki belge Divriği Belediyesinden çalışmaya dâhil edilmek üzere temin edilmiştir. Çiğdemli Köyü'nün diğer adı olan Ağılcık Köyü olarak anıldığı bu belgede köyde yer alan evlerin mimari üslubunun Osmanlı dönemine ait olduğu, gözlemler sonucunda evlerin tahrip olduğu tespit edilmiştir. Çiğdemli Köyü ile ilgili ayrıntılı bir tanım yapılmış olmakla birlikte bu tanım şu şekilde metin haline getirilmiştir: Yaklaşık kare planlı olarak yöreye özgü düz ve yassı sal taş malzemeden doğu cepheden zemin + ara kat +1 katlı olarak, batı cepheden ise $Z+1$ katlı olarak tek yöne eğimli çatılı galvanizli sac ile inşa edilmiştir. Konuta giriş batı cephede yer alan ahşap malzemeden tek kanatlı bir kapı ile 
sağlanmaktadır. Konutun doğu-batı cephesi eğimli araziye göre yerleştirilmiştir. Doğu cephesinde birinci kat hizasında cephe boyunca çıkma görülmekte olup, çıkmanın merkezinde ahşap çıtalarla desteklenmiş ahşap malzeme ile yapılmış bir balkon bulunmaktadır. Balkonun her iki tarafında pencereler görülmekle birlikte sol cephede 4 adet dikdörtgen formda pencerenin olduğu, sağ cephede ise bulunan pencerelerin oldukça tahrip olduğu görülmüştür. Bu pencerelerin hemen üstüne kare formda küçük bir açıklık yerleştirilmiştir. Konut günümüzde tahrip olmuştur. Doğu cephesi önünde bir patika yol bulunmakta olup, batı cephesi önünden dar bir toprak yol geçmektedir. Köyün bakımından sorumlu olması gereken kişi/kuruluşların özel mülkiyet olması gerektiği görüşüne varılmıştır. Ayrıca Çiğdemli Köyünün sahip olduğu kültürel dokunun gösterildiği bazı fotoğraflar Şekil 3. Başlığı altında sunulmuştur (Divriği Belediyesi).

Evlerin tahribat düzeyinin yüksek olmasına rağmen yılda yaklaşık 2000 kişinin ziyaret ettiği destinasyon olan Çiğdemli Köyü'nün alt yapı çalışmaları büyük çoğunlukla tamamlanmış olup, üst yapı çalışmalarına da başlanmıştır. Köyde bulunan evlerin sahip olduğu tarihi doku korunarak iyileştirme faaliyetleri yapılmaktadır. Ayrıca köye ulaşımın kolay hale getirilmesi için köy yolu çalışmaları devam etmektedir. Divriği Ulu Cami ve Darüşşifası ile diğer tarihi yerlerin gezilmesi amacıyla turist taşıyan tur şirketlerinin gezi rotalarına Çiğdemli Köyü’nün de eklenmesi amaçlanmaktadır. Tanıtım faaliyetlerine yönelik hali hazırda çalışma sayısı azdır. Fakat köyün koruma altına alınması ile birlikte sahip olduğu çekiciliğin turistik talebi artıracağ 1 görüşünden hareketle tanıtım ve pazarlama faaliyetleri konusunda ihtiyacın ortaya çıkacağı düşüncesiyle, turistlerin zihinlerinde konumlandırma yapılması için yerel ve ulusal kanallarda yayınlatılmak üzere geniş kapsamlı belgesel çekilmesi gündemdedir. Köy ile ilgili basın yayın organlarında çıkan haberlerin tanıtım faaliyetleri açısından önemli olduğu görüşü de benimsenmiş ve bununla ilgili çalışmalar yapılması planlanmaktadır.

Tanıtım ve pazarlama faaliyetleri konusunda yapılacak olan etkinliklerin artmasıla birlikte ilçe ekonomisinin de ciddi katk1 elde edeceği düşünülmektedir. Çok kültürlülüğün çekicilik sağlamasının yanı sıra sahip olduğu birçok tarihi ve kültürel değerler ile turizm anlamında Divriği ilçesi ekonomik getirisi iyi olan bir ilçe konumundadır. Ayrıca yerel halkın ve yerel yöneticilerin turizme bakış açısı oldukça olumludur. İlçe halkı gelen yerli ya da yabancı turistlere karşı son derece hoşgörülü davranmaktadır. Dolayısıyla Çiğdemli Köyünün ilçe turizmine kazandırılması için gerek Sivas Valiliği ve ilçe yönetimi, gerekse ilçe halkı tarafından destekler devam etmektedir. Köyün sahip olduğu turizm potansiyelinin kullanılması için valilik ve belediye bünyesinde çalışmalar yürütülmektedir. Bununla birlikte özellikle sit alanı olarak koruma altına alınmasıyla turizm merkezi haline dönüştürülmesi için yapılacak faaliyetlerin hız kazanması beklenmektedir.

Çiğdemli Köyü ile ilgili Divriği Belediyesinden ve Çiğdemli Köyü derneğinden toplanan bilgi ve belgelerin yanı sıra yapılan taramalar sonucunda pek çok yayın organında Çiğdemli Köyü hakkında haberler yapıldığı görülmüştür. Bu yayın organlarından bazıları şu başlık ve içerikler ile Çiğdemli Köyünü haber yapmışlardır:

- “Orta Çağ seti değil, Sivas'ın Çiğdemli Köyü: Orta Asya'dan Anadolu'ya göçen Türklerin ilk uğrak yerlerinden biri olan Sivas'ın Divriği ilçesindeki eski adı ile Tuğut, yeni adı ile Çiğdemli Köyü benzersiz mimarisi ile öne çıkıyordu. Evliya Çelebi'nin Seyahatname isimli eserinde "150 haneli, bağl1-bahçeli, mamur bir köy" sözleri ile bahsettiği köy, Sivas Valiliği'nin girişimleriyle SİT alanı ilan edilerek koruma altına alındı. Yaklaşık bin yıllık olduğu düşünülen köydeki evler bitişik yapıları ile Mardin evlerini de andırıyor. Evler arasında birbirine bağlanan tüneller, köprüler bulunduğu gibi bazı evlerin altında tünellerden ulaşılan mahzenler yer alıyor. Köy dar sokakları, taş duvarları, tavan işlemeleri ve tarihi kaldırımları ile adeta bir Orta Çağ filmi setini andırıyor. Nizami mimarisi ile de günümüz mimarları için bulunmaz bir örnek teşkil ediyor" (URL 4).

- "Sal taşından yapılan evleriyle Çiğdemli Köyü: Köyün dar ve eğimli araziye yerleşmiş dik sokakları taştan döşenmiş ve yapıların eteklerinde taştan kaldırımlar bulunuyor. Yaklaşık 800 yıllık tarihi ile Türklerin civardaki en eski yerleşim yerlerinden biri olarak bilinen köyde bulunan evler, görenleri kendisine hayran bırakıyor. Yüzyıllar önce taş ocaklarından toplanarak köye getirilen yöreye özgü düz ve yassı sal taşı ile yapılan evler dikkat çekiyor. Birçok eski binanın bulunduğu köydeki evler yöreye özgü 'kırlangıç kanadı' örgü sistemi ile yapılıyor. Evlerde taş ve ahşabın birlikte kullanılmasıyla oluşan etkileyici cephe düzeni, evlerin tasarım çeşitliliğiyle birlikte bütünleşen bir mimari denge oluşturuyor. Erzincan depremi sırasında köyde şiddetli sarsıntı yaşandığı, fakat evlerin sağlam olmasından kaynaklı taşın taş üstüne düşmediği ifade edilmiştir” (URL 6). 
-"Sivas'ta 800 yıllık köy: Sal taşından evler hayranlık uyandırıyor: Divriği ilçe merkezine 20 kilometre uzaklıkta bulunan eski adı 'Tuğut' olan Çiğdemli Köyü, bir dönem Erzincan'ı Malatya'ya bağlayan eski yol üzerinde yer alıyor. Köyün dar ve eğimli araziye yerleşmiş dik sokakları taştan döşenmiş ve yapıların eteklerinde taştan kaldırımlar bulunuyor. Yüzyıllar önce taş ocaklarından toplanarak köye getirilen yöreye özgü düz ve yassı sal taşı ile yapılan evler dikkat çekiyor. Evlerde taş ve ahşabın birlikte kullanılmasıyla oluşan etkileyici cephe düzeni, evlerin tasarım çeşitliliğiyle birlikte bütünleşen bir mimari denge oluşturuyor" (URL 7).

- "Orta Çağ film setlerini andıran Çiğdemli Köyü Si̇T alanı ilan edildi: Orta Asya'dan Anadolu’ya göçen Türklerin ilk uğrak yerlerinden biri olan Sivas'ın Divriği ilçesindeki eski adı ile Tuğut, yeni adı ile Çiğdemli Köyü benzersiz mimarisi ile keşfedilmeyi bekliyordu. Evliye Çelebi'nin Seyahatname isimli eserinde konu ettiği köy, yaklaşık 150 haneden oluşuyor. Köydeki evler kendine özgü ilginç mimarileri ile dikkat çekiyor. Yaklaşık bin yıllık olduğu düşünülen köydeki evler bitişik yapıları ile Mardin evlerini de andırıyor. Evler arasında birbirine bağlanan tüneller, köprüler bulunduğu gibi bazı evlerin altında tünellerden ulaşılan mahzenler yer alıyor. Köy dar sokakları, taş duvarları, tavan işlemeleri ve tarihi kaldırımları ile adeta bir Orta Çağ filmi setini andırıyor. Nizami mimarisi ile de günümüz mimarları için bulunmaz bir örnek teşkil ediyor” (URL 5).

- "Eşi benzeri yoktu, koruma altına alındı: Geçmişi çok eskilere dayanan Divriği ilçesindeki eski adıyla Tuğut, yeni adıyla Çiğdemli Köyü olarak bilinen yerleşim yeri SíT alanı ilan edildi. Sivas Valiliği tarafından yapılan girişim sonucu Divriği ilçesinin Çiğdemli Köyü SİT alanı ilan edildi ve koruma altına alındı. Evliya Çelebi tarafından kaleme alınan meşhur Seyahatname eserinde de bahsedilen köydeki yapıların günümüzde eşi benzeri yok. Görülmeye değer mimarisiyle çok sayıda vatandaşın her yıl ilgisini çeken ve ziyaretçi akınına uğrayan bölge artık 2863 sayılı Kanun kapsamında Korunması Gerekli Taşınmaz Kültür Varlığı olarak tescil edilmiş durumda bulunuyor. Mardin evlerini de andıran bitişik ve kendine has mimarisi ile ilgi çeken Çiğdemli Köyünde ilk yaşayan topluluğun Romalılar olduğu düşünülüyor” (URL 2).

Görüldüğü üzere Çiğdemli Köyü tarih sahnesinde yaklaşık bin yıldır yıkılmadan ayakta kalmayı başarabilmiş ender destinasyon mekânlarından birisidir. Turizm alanında ülkeye kazandırılması uygun görülmüş olup bu konudaki hassasiyet koruma altına alınması ile devam etmektedir.

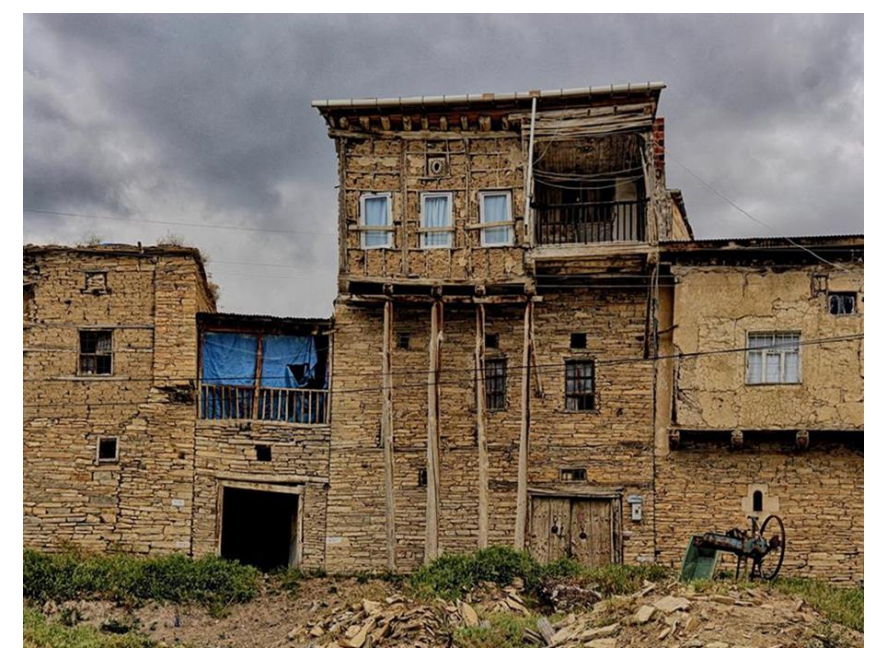

Şekil 3. Çiğdemli Köyü’nden Manzaralar 1 

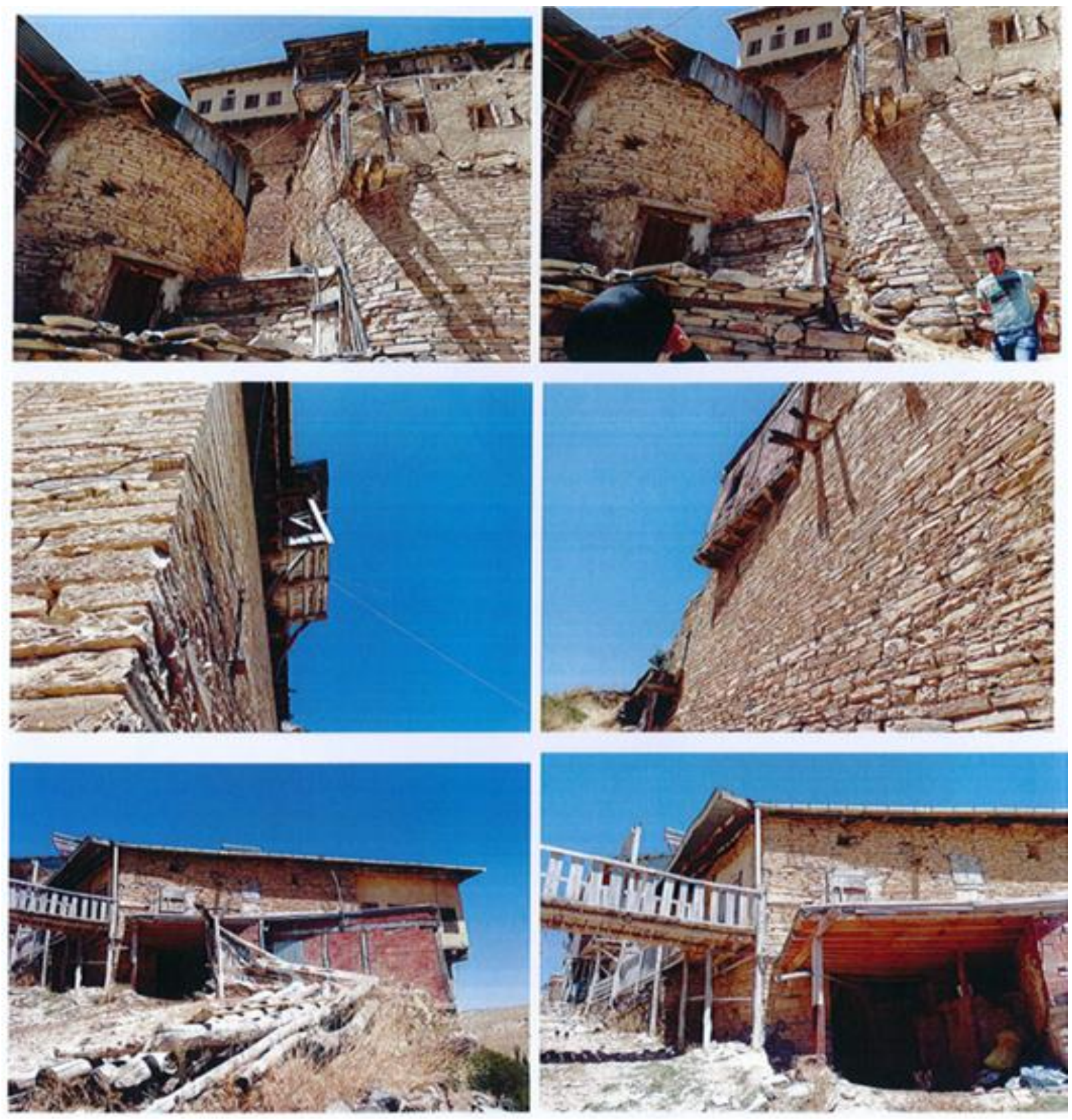

Şekil 3. Çiğdemli Köyü’nden Manzaralar 2

\section{SONUÇ:}

Divriği ilçesi çok kültürlü yaşamın devam ettiği bir ilçe olarak, birçok tarihi ve kültürel çekicilikleri olan yüksek turizm potansiyeline sahip bir destinasyondur. Doğal yapısı ve beşeri yetenekleriyle doğal ve tarihi açık hava müzesi niteliğinde olmakla birlikte her yıl binlerce turisti ağırlamaktadır. Günümüzde demiryolu, karayolu gibi ulaşım araçlarıyla ilçeye ve köylerine ulaşım büyük ölçüde mümkün olmaktadır. İlçenin merkeze ve büyük şehirlere olan uzaklığı, sahip olduğu tarihi ve kültürel değerlerin tam olarak farkında olamama, turizm hizmetleri konusundaki yetersizlikler gibi olumsuzluklara rağmen turizm anlamında farkındalık kazanmış bir yerleşim yeridir. Özellikle Divriği Ulu Cami ve Darüşşfası başta olmak üzere konakları, hanları, hamamları ile de turistik çekim merkezi olmayı başarmış bir ilçedir. 
Divriği ilçesinde yer alan Çiğdemli Köyü de eşsiz tarihi dokudaki evleri ile turizme yeni bir bakış açısı kazandırılmasını sağlayacak potansiyele sahiptir. Köyün tarihi dokusunun korunabilmesi amacıyla koruma altına alınmış, bununla birlikte farkındalık yaratılarak, insanlar tarafından keşfedilmesinin yolu açılmış olmaktadır. 22.06.2020 tarihinde, 6080 sayılı kararı ile Kültür ve Turizm Bakanlığı Kültür Varlıkları ve Müzeler Genel Müdürlüğü tarafından kültürel miras olarak sit alanı şeklinde koruma altına alınan Çiğdemli Köyü geçmişten günümüze gelinceye kadar pek çok medeniyete ev sahipliği yapmış bir destinasyon mekânıdır. Bununla birlikte köyde yer alan yapılar büyük ölçüde tahrip olmuş olup, bununla ilgili gerekli çalışmalar devam etmektedir.

Köyün keşfedilmesine katkı sağlamak ve daha fazla sayıda yerli ve yabancı turistin köyü ziyaret etmesini sağlamak amacıyla yapılan bu araştırma sonucunda toplanan belge ve bilgiler neticesinde şunlar tespit edilmiştir:

- Çiğdemli Köyünün bir kültürel miras olarak destinasyon mekânı olduğu,

- Çiğdemli Köyünün koruma altına alınmasının gerekliliği sonucu Kültür ve Turizm Bakanlığı tarafından 22.06.2020 tarih ve 6080 sayılı karar ile sit alanı olarak koruma altına alındığı,

- Çiğdemli Köyünün alt yapı çalışmalarının büyük ölçüde tamamlandığı,

- Çiğdemli Köyüne ulaşımın rahatlıkla sağlanmasına imkân tanıyacak üst yapı çalışmalarına hız verildiği,

- Çiğdemli Köyünde bulunan evlerin sahip olduğu tarihi doku korunarak iyileştirme faaliyetleri kapsamında yapılan çalışmalara devam edildiği,

- Çiğdemli Köyünün turistik çekim merkezi haline gelmesi için gerekli tanıtım faaliyetlerinin yapılmaya devam edildiği,

- Çiğdemli Köyünün tanıtımına ilişkin pazarlama faaliyetlerinin henüz istenilen düzeyde olmamasına ve gerekli fiziki iyileştirmelerin tam olarak bitirilmemesine rağmen yılda yaklaşık 2000 kişinin köyü ziyaret ettiği,

- Çiğdemli Köyü ile ilgili birçok basın yayın organında haberlerin yapılarak farkındalık sağlanmaya çalışılması,

- Divriği ilçe halkının olduğu kadar Çiğdemli Köyü halkının da gelen turistlere karşı yaklaşımının hoşgörülü olduğu,

- Divriği Ulu Cami ve Darüşşifası ile diğer tarihi yerlerin gezilmesi amacıyla turist taşıyan tur şirketlerinin gezi rotalarına Çiğdemli Köyünün de eklenmesinin amaçlandığı,

- Çiğdemli Köyü ile ilgili olarak yerli ya da yabancı turistlerin zihinlerinde konumlandırma yapılması amacıyla yerel ve ulusal kanallarda yayınlatılmak üzere geniş kapsamlı belgesel çekilmesinin gündemde olduğu sonuçlarına varılmıştır.

Bununla birlikte Çiğdemli Köyünün mevcut potansiyeli de göz önüne alınarak bir destinasyon mekânı olarak daha etkin bir şekilde nasıl pazarlanması gerektiği hakkında şu önerilerde bulunulabilir:

- Köyün destinasyon pazarlaması unsurları kapsamında konumlandırmasının yapılması,

- Destinasyon imajının oluşturulması için gerekli tanıtım faaliyetlerine hız kazandırılması,

- Markalaşma konusunun önemine dikkat çekilmesi,

- Yerel halkın daha fazla bilinçlenmesini sağlamak amacıyla gerekli bilgilendirme çalışmalarına hız verilmesi,

- Araştırma zaman kısıtı nedeniyle toplanan dokümanların incelemesi ve gözlem sonucu elde edilen bilgiler 1şı̆̆ında yapılmıştır. Daha sonraki çalışmalar için gerek ilçe yönetimindeki kişiler, gerekse ilçe ve köy halkı ile yüz yüze görüşmeler yapılmak suretiyle Çiğdemli Köyü ile ilgili geniş bir veri setine ulaşma imkânı elde edilebilecektir. 


\section{Etik Standart ile Uyumluluk}

Çıkar Çatışması: Herhangi bir çıkar çatışmasının olmadığını beyan ederim.

Etik Kurul İzni: Bu çalışma için etik kurul iznine gerek yoktur.

Finansal Destek: Yoktur

\section{KAYNAKÇA:}

Aksoy, A., Enlil, Z., Ünsal, D., Pulhan, G., Dinçer., İ., Gülersoy, Zeren, N., Ahınbay, Z. \& Köksal, G. (2012). Kültürel Miras Yönetimi. 1. Baskı, Eskişehir: Anadolu Üniversitesi Web-Ofset.

Ashworth, G.J. \& Voogd, H. (1994). Marketing and Place Promotion, in Gold. J.R. \& Ward, S.W. (Ed.), Place Promotion, the Use of Publicity and Marketing to Sell Towns and Regions içinde (39-53). Chichester: John Wiley \& Sons.

Bahar, O. ve Kozak, M. (2005). Küreselleşme Sürecinde Uluslararası Turizm ve Rekabet Edebilirlik. Ankara: Detay Yayıncilik.

Kotler, P. (1997). Marketing Management: Analysis, Planning, Implementation and Control. Inc., 9th ed., New Jersey: Prentice Hall International.

Kotler, P., Asplund, C., Rein, I. ve Haider, D. (1999). Marketing Places Europe. London: Pearson Education Ltd,

Kotler, P., Hamlin, M. A., Rein, I. \& Haider D. H. (2002). The Marketing Challenge in the New Asia. J. Wiley ve S. (Asia), Pte Ltd (Ed.), Marketing Asian Places. Attracting Investment, Industry, and Tourism to Cities, States and Nations içinde (4). Singapore.

Kotler, P. ve Gertner, D. (2002). Theoretical papers. Country as Brand, Product, and Beyound: A Place Marketing and Brand Management Perspective. Special Issue Brand Management, 9(4-5), April 2002, 249-261. (15.09.2020) tarihinde https://edisciplinas.usp.br/pluginfile.php/1680885/mod_resource/content/1/Artigos/Country_as_brand.pdf adresinden erişildi.

Porter, M. (2001). Regions and the New Economics of Competition. A.J. Scott (Ed.), Global City-Regions, Trends, Theory, Policy içinde (155-156). Oxford University Press.

URL 1: (b.t.), http://www.cigdemlikoyu.com/Page2.aspx, (Erişim Tarihi: 23/09/2020).

URL 2: (2020), https://www.sivashaberler.com/cigdemli-koyu/, (Erişim Tarihi: 23/09/2020).

URL 3: (b.t.), https://www.ktb.gov.tr/TR-96254/kultur.html, (Erişim Tarihi: 23/09/2020).

URL 4: (2020), https://www.haberturk.com/orta-cag-seti-degil-sivas-in-cigdemli-koyu-2765053, (Erişim Tarihi: 16/09/2020).

URL 5: (2020), https://www.ntv.com.tr/galeri/sanat/orta-cag-film-setlerini-andirancigdemli-koyu-sit-alani-ilan edildi,EtqwLNOVOUC247c-n3tAWQ, (Erişim Tarihi: 16/09/2020).

URL 6: (2020), https://www.trthaber.com/haber/yasam/sal-tasindan-yapilan-evleriyle-cigdemli-koyu-433193.html, (Erişim Tarihi: 16/09/2020).

URL 7: (2019), https://www.yenisafak.com/gundem/sivasta-800-yillik-koy-sal-tasindan-evler-hayranlik-uyandiriyor3508141, (Erişim Tarihi: 16/09/2020). 
URL 8: (b.t.), https://ich.unesco.org/doc/src/00009-TR-PDF.pdf, (Erişim Tarihi: 19/09/2020).

URL 9: (b.t.), https://www.unesco.org.tr/Pages/161/177, (Erişim Tarihi: 16/09/2020).

URL 10: (b.t.), https://sozluk.gov.tr/, (Erişim Tarihi: 16/09/2020).

URL 11: (b.t.), UNESCO. https://www.unesco.org.tr/Pages/126/123/UNESCO\%C4\%B0nsanl\%C4\%B1\%C4\%9F\%C4\%B1n-Somut-Olmayan-K\%C3\%BClt\%C3\%BCrel-Miras\%C4\%B1Temsil\%C3\%AE-Listesi, (Erişim Tarihi: 16/09/2020).

URL 12: (b.t.), http://www.icomos.org.tr/Dosyalar/ICOMOSTR_tr0243603001536681730.pdf., (Erişim Tarihi: $16 / 09 / 2020)$. 